\title{
Music, Community, and Middleton's Anti-Masque in The Witch
}

\begin{abstract}
This essay argues that the musical performances in Middleton's The Witch (ca 1616), largely dismissed by critics as unsophisticated spectacles, are some of the play's most innovative features. The witches' songs implicitly critique the patriarchal order that has led to the dysfunctional intrigues of the courtly world from which they are excluded and offer the audience an alternative centred on a joyful, supportive community of women. To do this, Middleton's play appropriates and subverts the musical dynamics of Ben Jonson's Masque of Queens (1609), deconstructing conventional associations between music and social harmony, and invites the audience to explore alternative social formations.
\end{abstract}

No one takes a singing witch seriously anymore. Just ask Hecate, the singing, dancing star of Thomas Middleton's The Witch (ca 1616). ${ }^{1}$ Hecate's musical performances were apparently spectacular enough to warrant pride of place in the play's title despite her actual role being relegated to just three scenes that are largely tangential to the intrigues and betrayals of its central revenge plot. Her talents also probably landed her an important cameo appearance alongside the more famous singing witches in Macbeth, where two whole scenes, including a song and a dance borrowed from The Witch, seem to have been added just for her. ${ }^{2}$ Certainly, at least a portion of the play's early modern audience was likely to have taken its singing witches seriously. Witches were complex figures in the period - cultural sites of scepticism and belief, fascination and danger. In the London playhouses witches were figures of the imagination and certainly of entertainment. But in rural towns and villages all over the country they were also real women who faced trials and executions. And Hecate's songs themselves would have been no less complex as sites of cultural tension: charms, chants, and songs share conceptual roots, ${ }^{3}$ and vibrant debates over the place and value of music in religious, public, and private life were common throughout the period. ${ }^{4}$

Andrew Loeb (andrewloeb@trentu.ca) is assistant professor in the department of English at Trent University, Ontario, Canada. 
Yet if you ask modern critics of The Witch's musical material, Hecate, her coven, and their spectacular song and dance numbers are just that: spectacles - comic curiosities introduced to capitalize on the witchcraft vogue born, at least in part, of James I's famous fascination with the subject, and convenient excuses for the exciting theatrical effects afforded by the Blackfriars theatre's stage machinery. ${ }^{5}$ Musical witches, in other words, put bums in seats but offer little in the way of real artistic value.

In this essay I take Middleton's singing witches seriously and suggest that their music is one of the most important and innovative features of The Witch. Far from being merely spectacular but harmless appendages to the play's central intrigues, I argue that Hecate and her coven use songs to forge a vibrant sense of communal identity, a shared solidarity that resists and alleviates their marginal status on the outskirts of the play's normative social world - the badly dysfunctional court of Ravenna. The songs likewise offer an implicit critique of the social order that structures the court - pervaded by both overt and covert instances of patriarchal dominance - that has led to that dysfunction by encouraging the audience to envision an alternative centred on a joyful, supportive community of rebellious women. I contend that in order to accomplish these sophisticated dramatic functions, Middleton's play interpolates and inverts the musical conventions of the court masque, and particularly Ben Jonson's Masque of Queens (1609), which frames witches as the unruly others against which English royal power, in the figure of the king and court, can be defined and authorized as a source of stability, order, and virtue. Middleton's play adapts and satirizes the conventions of representation embodied in the masque form to critique the politics of community identity those representations produce. Jonson's antimasque uses music to position its witches as symbolic figures of disturbance and disruption that are marked and contained as disorderly others in order to define and produce English royal authority, social order, and collective identity. Middleton's musical coven, on the other hand, performs a witchy inversion, deliberately deconstructing conventional associations between musical and social harmony, and inviting their audience to explore alternative social formations.

More than two decades have elapsed since Diane Purkiss first noted that criticism of The Witch tends to focus overwhelmingly on its relationship to works and events outside of itself. ${ }^{6}$ These include Macbeth, which interpolates the character of Hecate and a pair of songs from Middleton's play, the Essex divorce scandal, which the play obliquely dramatizes and for which it may have been censored, ${ }^{7}$ and indeed The Masque of Queens, from which Middleton's play may have incorporated costumes, stage properties, and music. ${ }^{8}$ The result is that 'these readings 
of The Witch subordinate it to another text deemed more original and authoritative: whether seen as fashionable, exploitative, or scandalous, The Witch is always seen as a recapitulation of a story from elsewhere.' In reconsidering The Witch's relationship to The Masque of Queens, I recognize that I risk reproducing the very problem Purkiss identifies. But I hope to show here that Middleton's play is not merely a recapitulation or reconfiguration of a more original story, but rather a sophisticated response to an established set of tropes for representing witches through music, of which Queens is simply the most pertinent and powerful exemplar. Middleton's play, I suggest, is keenly aware of the conventions it borrows from Jonson's masque, and indeed other entertainments centred on witches, and deftly reconfigures them into a kind of anti-antimasque that satirizes Jacobean assumptions about normative forms of order and power. ${ }^{10}$

Even when The Witch is considered on its own terms, however, discussions of the witches and their music tend overwhelmingly to emphasize their role as figures of entertainment, spectacle, and comedy - temporarily disruptive, but ultimately harmless. When the music is mentioned at all, critics of The Witch emphasize its atmospheric qualities, the 'positively celebratory air' created by 'stage spectacle, music, dance, and ritual', 11 its contribution to 'the strange, asymmetrical world of chaos and disorder that the witches represent by their inversion and perversion of all things normal', ${ }^{12}$ or the role it plays in making the witches 'figures of the nascent entertainment industry rather than figures of the demonic. ${ }^{13}$ Others gloss over the music entirely, relegating Hecate and her coven to 'a fantastic ... tongue-in-cheek, caricature of witches. ${ }^{14}$ Even Purkiss, whose discussion of The Witch appears in a chapter called 'The All-Singing, All-Dancing Plays of the Jacobean Witch-Vogue', makes no explicit mention of the play's music except to acknowledge its probable material borrowings from The Masque of Queens, while noting elsewhere that 'Hecate is presented as comically rather than sinisterly grotesque; she does not have any power over the public sphere, and her power in the private sphere, though real, is devalued as trivial by virtue of the very fact that the play's lengthy displays of witchcraft "lore" are not fully integrated into the main plot'. ${ }^{15}$ Only Amanda Eubanks Winkler's musicological reading of the play acknowledges in any real detail its debt to Jonson's masque and the role its music plays in producing 'a disturbingly symbiotic relationship between witch and noble. ${ }^{16}$ The effect of this general dismissal has been to turn Middleton's witches into quaint curiosities, and to divest them of any lasting significance in terms of our understanding of both the play itself and of English representations of witchcraft more generally. 
In the early modern English imagination, witches played a crucial role in the conceptualization and articulation of normative behaviour, morality, and identity. Ian Bostridge notes that early modern witchcraft theory (that is, elite, learned writing about witches produced by the ruling classes) set men and women who had contracts with the devil to do harm to their communities in opposition to both divine and social orders making it 'as much a social, political, and theological theory as a natural one. ${ }^{17}$ The absolute centrality of such oppositions to demonological writing is the subject of much of Stuart Clark's influential scholarship on witchcraft and the supernatural, which he argues 'shared a vocabulary of misrule', where the symbolism and ideas associated with witches were 'part of a language conventionally employed to establish and condemn the properties of a disorderly world'. ${ }^{18}$ The two sides of this opposition were thus mutually constitutive: 'witchcraft was only the crime it was, and the duty to punish it could be seen as religious, in those areas of political culture that were very largely committed to theocratic principles and where authority was inherently sacred' such as divine-right monarchies. ${ }^{19}$ Peter Elmer's recent work on the neglected interrelationship between witchcraft theory and actual witch-hunting practices makes this dynamic even clearer and explicitly implicates the practices of the court masque in the production and maintenance of binary oppositions between the ordered hierarchy of the court and the threat of devilish disorder. According to Elmer, 'the idea of diabolical disorder provided a valuable counterfoil to the order and decorum of divine right monarchy, a lesson in mystical politics that found concrete expression at the court of the early Stuarts in the guise of the masque and anti-masque'. ${ }^{20}$ In England witches represented a radically other 'them' that could make intelligible an English 'us' (just, moral, patriarchal, Protestant and, above all, orderly) and bring it into sharper focus. Witches were manifestations of the disorder, irrationality, and difference that threatened the implicitly ordered, rational, and unified English world. ${ }^{21}$

Music was a natural complement to the social function that representations of witches carried out in early modern discourses of identity and power, especially in explicitly ritualized artistic forms like the court masque. As Eubanks Winkler succinctly puts it, masques regularly drew on familiar Neoplatonic notions of music wherein 'musical harmony represented divine harmony and the harmonious relationship between divinely appointed monarch and subject. Dissonant or harsh, noisy sounds symbolized violence, conflict and subversion.'22 Jonson's Masque of Queens was the first masque to fully unite English witchcraft beliefs and English attitudes toward music in service of the symbolic production of English communal identity. ${ }^{23}$ Jonson recognized in the spectacle of the singing, dancing 
witches that fascinated James I both a clear and present danger (James reportedly believed he had personally been the target of witchcraft ${ }^{24}$ and the Essex divorce scandal purportedly involved more than one instance of magical intervention $^{25}$ ) and a complex web of ideas, anxieties, associations, and behaviours that screamed - perhaps literally — otherness, unruliness, danger, and disorder. By staging a witches' sabbat accompanied by dissonant musical charms and unruly dancing that is ultimately banished by the triumphant harmony of beautiful and virtuous queens, Jonson maximizes the audio-visual potential of the antimasque/ masque dynamic to symbolically legitimize English royal authority as a source of social order and security in contrast to forces of disorder and unruliness.

Jonson's allegorical strategy works in part, as the quote from Eubanks Winkler above suggests, because music, like witches, played a key role in early modern philosophical and popular thought alike in conceptualizing and articulating the fundamental order that underpinned the cosmic, social, and individual realms of English life. The Platonic notion of the music of the spheres, the idea that the whole of creation was ordered according to divine proportions imperfectly reflected in the earthly audible music made by human beings, was echoed regularly in a wide range of sources that described social order and hierarchy in musical terms. In an early example from the period, Thomas Elyot, in his Book Named the Governor (1537), advocates for the inclusion of music in the education of young people, 'for the better attaining the knowledge of a publyke weale. Which, as I before sayd, is made of an ordre of astates and degrees, and by reason thereof, conteyneth in it a perfect harmony'. ${ }^{26}$ In the popular theatre, Shakespeare later framed the dangers of ignoring or abandoning natural social hierarchies in musical terms as well, when Ulysses, in Troilus and Cressida (ca 1603) warns, 'Take but degree away, untune that string, / And hark what discord follows' (1.3.109-10). ${ }^{27}$ The idea of music situated amidst a much larger network of ideas and significations having to do with order, proportion, and concord was, for early modern English writers, a ready-at-hand conceptual resource for imagining and idealizing society itself. Like beautiful music, the ideal society consisted of many parts, each finding its appropriate place in the whole and producing a greater overall harmony.

But communities in early modern England were conceptualized and defined as much through musical practices, and music's physical sounds and rhythms, as they were through musical theories and symbolisms. Christopher Marsh notes that in early modern England, 'Music was most commonly experienced socially, and its hearers were automatically defined as some sort of a collectivity merely through their physical positioning within a shared auditory field', a phenomenon he ascribes to music's capacity to 'generate similar and simultaneous feelings in 
a range of listeners'. ${ }^{28}$ Bruce R. Smith, in his landmark work on how early moderns understood communal identity and navigated social spaces through sound, identifies what he calls 'acoustic communities ... maintained not only by what its members say in common but what they hear in common' and notes that sonic features like the ringing of church bells, for example, acted as 'soundmarks' by which people oriented themselves both socially — as part of a particular community and geographically: "The community as a whole sits within its own "acoustic horizons", charted not only by the distinctive sounds that emanate from within but also by the sounds that come from without. Bells from the next parish serve as a reminder of both differences and commonalities. ${ }^{29}$ Smith is concerned primarily with non-musical sound, but a wide variety of musical performances were regular features of any given soundscape in early modern England. Wes Folkerth has argued for the prominent role that town waits - musicians employed by each municipality - played in the production of community, since they were 'expected in many towns to sound curfew along a specified route, and to play the people awake in the early morning. ${ }^{30}$ A particular group of musicians, their song choices, and their specific style of playing would thus function as one of the acoustic properties that defined a given town or neighbourhood and its inhabitants. And given music's ubiquity in the early modern English day-to-day, pervading communal spaces such as taverns, feasts, country festivals, theatres, and court entertainments, it was inextricably connected to the experience of normal social life. ${ }^{31}$ Finally, David Lindley pinpoints the theatre as a uniquely potent locus for such musical community-building in early modern England, noting that, 'At the most basic level, characters within [plays] often establish their own sense of community through music and dance. But, at the same time, the music they play reaches out to the audience and may — though it need not — bind them into common feeling or response to the performed action. ${ }^{32}$ Both the overall English soundscape and specific musical practices functioned as especially potent markers of spatial and temporal location and of participation within particular communities. ${ }^{33}$

Jonson, in his masque, and Middleton, in his play, are both highly attuned to the soundscape and deftly deploy music's speculative and practical resonances with ideas of community and identity to forge and disrupt those identities respectively. In what follows, I briefly examine Jonson's Masque of Queens as an example of how music could be mobilized in service of the imaginative construction of the witch as an unruly other against which royal authority and English communal identity could be defined through difference. I will then turn to The Witch to 
demonstrate how Middleton deconstructs and reconfigures such ideological uses of music and appropriates them for court satire.

Jonson's Masque of Queens, commissioned by Queen Anne and performed at Whitehall on 2 February, 1609, adopts a conservative musical thinking. It leverages music's neoplatonic symbolism and the network of ideas to which music was connected in the early modern imagination to produce a status quo social order centered on the power of the king as its source, legitimized by the participation of the nobility in the reification of that power. Court masques, after all, had a fairly explicit social function - they celebrated English royal authority as the fount from which virtue and order sprang along with the stable national and communal identity made possible by identification with that sense of order. Where The Masque of Queens differs from its Tudor and early Stuart predecessors is in the innovation of the antimasque that preceded the masque proper. As Jonson notes in the preamble to the published version of the masque he made available shortly after its performance, his 'celebration of honorable and true fame bred out of virtue' (6) would be juxtaposed with 'a foil, or false masque' that depicted 'twelve women in the habit of hags or witches, sustaining the persons of Ignorance, Suspicion, Credulity, etc.' (12-16). ${ }^{34}$ Such binaries were crucial to the political function of the Jonsonian masque/antimasque dynamic, which emerged at 'a moment in which the English court, representing (in its own estimation) the English nation, struggled to identify itself not only with the qualities and values it possessed but by those it opposed as well'. ${ }^{35}$ Jonson's antimasque of witches in Queens, 'a spectacle of strangeness, producing multiplicity of gesture, and not unaptly sorting with the current and whole fall of the device' (17-19), represents a corrupt and disorderly otherness that brings the orderly English nation into sharper relief.

Jonson's representation of disorder in the antimasque is thoroughly multimedia, exploring unruliness acoustically as least as much as it does visually. The masque begins with the scene of 'an ugly hell' and the playing of 'a kind of hollow and infernal music' to accompany the witches' entrance, 'all differently attired: some, with rats on their head, some on their shoulders; others with ointment pots at their girdles; all with spindles, timbrels, rattles, or other venefical instruments, making a confused noise, with strange gestures' (21-30). The emphasis on sound and music is important, highlighting sonically what the costumes and movements represent visually: that witches are radically disruptive to the political and social space of the court. ${ }^{36}$ In a culture that frequently resorted to musical metaphors to define and conceptualize cohesive social and political communities, disruptive and unrestrained music powerfully represented threats to social harmony. 
The disruption continues in the movement of bodies through the playing space when after a lengthy dialogue and a series of failed charms and invocations the 'hollow and infernal music' gives way to 'a strange and sudden music' and the witches begin 'a magical dance full of preposterous change and gesticulation, but most applying to their property, who at their meetings do all things contrary to the custom of men, dancing back to back and hip to hip, their hands joined, and making their circles backward, to the left hand, with strange fantastic motions of their heads and bodies' (327-32). Critics of the play largely agree that the dance described here was accompanied by a musical setting known as the 'Second Witches' Dance' found in British Library Add MS 10444, possibly composed by Robert Johnson. ${ }^{37}$ Eubanks Winkler argues that the setting's musical character supplements the unruly visual elaborated in Jonson's published account of the masque, marked by melodic and metrical instability that repeatedly subverts the listener's expectations until finally settling into a rustic dance. The effect is that the music is disruptive in a very particular way, progressing 'through chaos toward some degree of regularity, from uncontrolled disorder to mockable rusticity, drawing a musical line between the lower-class witches and the beauteous Queens. ${ }^{38}$ The witches are thus constructed by parallel visual and musical tropes as opposites to normative social behaviour and especially the expected conduct at a court masque.

Both the visual and sonic characteristics in Jonson's masque accord with Purkiss's notions of singing and dancing as strategies of containment for disruptive figures like witches - their appearances and the music that accompanies their dancing mark them as radically other to king and court. The danger of Jonson's witches is marginalized by exploiting their absurdity for the entertainment of the country's ruling class, 'appropriated to serve male political, social and intellectual agendas ... staged as a theatrical spectacle of otherness which exists to subtend the maintenance of hierarchy and order. ${ }^{39}$ Martin Butler adds to this marginalizing function an explicitly community-building one, arguing that masques are performances 'trading in stupendous images of sovereignty; shaped as acts of festive contest in which disorder is routed and subversion contained; and functioning as ceremonial arenas in which ritual exchanges between monarch and courtier mimed the ties of obligation bonding England's political elites'. ${ }^{40}$

These two symbolic functions of the masque - the containment of the other and the production of the normative community as its opposite - are most explicit in Queens at the moment of the witches' banishment from the performance space and the appearance of the queens. This occurs in the midst of the chaotic 'Second Witches Dance', which is suddenly interrupted by 'a sound of loud music, as if 
many instruments had made one blast; with which not only the hags themselves but the hell into which they ran quite vanished, and the whole face of the scene altered, scarce suffering the memory of such a thing' (334-7). The witches and their 'ugly hell' are then replaced by 'a glorious and magnificent building figuring the House of Fame, in the top of which were discovered the twelve masquers sitting upon a throne triumphal erected in form of a pyramid and circled with all store of light' (338-41). Of interest here is that music is the primary signifier for the transition from the disorderly, maleficent witches to the orderly, beneficent queens, and not merely an adjunct to its visual spectacle. ${ }^{41}$ The 'loud music, as if many instruments had made one blast' suggests raw power - since masques and other royal entertainments that could muster the enormous resources of the king's music were some of the few instances in which audiences could hear 'moments of totalized sound' 42 - but also unity, both harmonic and political. ${ }^{43}$ However visually spectacular and distinct the queens, their bodies, and their movements may have been from the unruly, dissonant, and grotesquely dancing hags they banish from the stage, the sonic field does the primary work of establishing otherness and rejecting it to produce a normative communal identity linked to the queens' laudable qualities - 'honorable and true fame, bred out of virtue' — while centring the king and his court as the wellspring of that identity.

The production of a normative English courtly identity through the spectacle of the masque was not only representational, but also participatory, 'encouraging identification between spectator and monarch, and endeavoring to create a climate of consensus and confidence. ${ }^{44}$ While the person of the king and the policies and ideologies he represented were explicitly centred in many ways, 'Masques [also] celebrated the court as a place with which all of the king's leading subjects could feel a measure of identification' ${ }^{45}$ In this sense, the marking of the witches as unruly others and their banishment in the transition between masque and antimasque is a symbolic extension of the masque's real-world mechanics: to define who is and is not a legitimate member of the court. Masques reify not only royal power, but also the courtly community authorized by participation in royal favour. ${ }^{46}$ This more general, participatory, community-building dimension culminates in the eventual erosion of the separation between the masquers and the audience in the masque revels, where the queens 'took out the men and danced the measures, entertaining the time almost to the space of an hour with singular variety' (Queens, 493-4). The masque revels were an opportunity for the audience to physically participate in the masque's symbolic reinstantiation of order, discipline, and harmony, 'wrapping performers in muscular and acoustic bonding' that 'sought to involve the audience in the court's vision of itself'. ${ }^{47}$ The 
masque's success thus depends in part on a temporary elision of the boundaries that ordinarily reinforce the essential fiction of theatrical performance: while the witches are a fictional threat, the production of harmony that replaces it involves the active participation of an audience willing to suspend disbelief momentarily and to become performers themselves, literalizing the masque's symbolism in their embodied participation. 'If the masque is to come alive', argues Mary Chan, 'it depends, more than any other form, on the sympathy between its actors and its audience where each takes on, partially, the role of the other'. ${ }^{48}$

The Stuart masque is a concatenation of complex social practices that not only reinforce the power and centrality of the king to the stability of the English nation in the face of threatening and chaotic others, but also produce the socio-political community and sense of national and civic identity upon which royal power itself depends. The Masque of Queens centres those social practices on music and dance. By staging the threatening other as a coven of cacophonous witches that is first banished by the queens' totalizing unison blast, and then replaced by harmonious sounds and the movements of bodies representing normative English identity, Queens demonstrates the central role that musical theories and practices played in imagining and producing social cohesion, group belonging, and political harmony. I now turn to The Witch to examine how it deconstructs and reconfigures these musical associations in the service of a biting satire of the fantasy of a social and political harmony centred on courtly and royal authority.

Where Jonson saw (and heard) in music a powerful imaginative resource for staging the masque's identity politics in service of his royal patrons, Middleton saw (and heard) an opportunity for satire and critique. Of the dramatic works that represent witches on the early modern popular stage, The Witch is the most thoroughly musical. Hecate and her coven, alongside a cadre of spirits and familiars, spend much of their stage-time singing and dancing. The effect of the musical performances is certainly comic and spectacular, but they also serve a more complex function in the play, offering its audience a glimpse of an alternative to the corrupt patriarchy of the royal court. Middleton's singing, dancing coven is, like the English court at the end of The Masque of Queens, a harmonious whole but that harmony is not merely symbolic. Hecate's coven is a supportive, joyful, playful community of women participating in shared activities and expressions of mutual support conducted mostly through music. The court of Ravenna, on the other hand, is a mess - embroiled in intrigues and immoralities that trickle down from its Duke's profound cruelties to its courtiers' murderous and lecherous machinations. Drawing on the same network of ideas connected to music as Jonson had earlier mustered for the Masque of Queens — and, indeed, directly 
appropriating some of Jonson's musical practices - Middleton's witches function not as an antimasque, but as an anti-antimasque, a spectacular performance that resists dysfunctional patriarchal authority in favour of an alternative social world populated by independent women that use their liminality as a source of social cohesion and group identity.

The main plot of The Witch, centred primarily on Ravenna, is a cacophony of overlapping intrigues: Sebastian arrives home from war to find his fiancée, Isabella, married to Antonio, who has spread false rumors of Sebastian's death. Sebastian solicits magical revenge from Hecate in the form of a charm that renders Antonio impotent only with Isabella. Almachildes desires Amoretta but is scorned by her and likewise seeks a charm from the witches to magically bind her affections. The Duke of Ravenna publicly shames and torments his wife - whom he has taken by force as a spoil of war - by toasting the new bride, Isabella, with a cup made from the skull of the Duchess's slain father (an insult which provokes the Duchess to seek her own murderous revenge). Francesca, Antonio's sister, is pregnant by Aberzanes, and fears for her life if she is discovered. These several plots intertwine as romantic interests are exploited for revenge or political gain, love charms are misused and misplaced, bed tricks are performed, and someone is murdered, then revealed to have been mistaken for someone else, and then further revealed never to have been murdered in the first place.

Against the backdrop of the relentless betrayal, manipulation, and violence that saturates the play's court environment, the witches don't seem especially disorderly or menacing. While they facilitate much of the intrigue and manipulation at court by providing charms to spur the various plot threads, the witches themselves are a surprisingly close-knit, functional community. The juxtaposition between court and coven suggests that Ravenna and the conventional forms of power it represents is deeply disordered and confronts the play's audience with the possibility that the nobles are not so different from the witches they fear and persecute. This eliding of difference is demonstrated through a number of key parallels between the two main groups scattered throughout the play's action and is further complicated through the use of music.

In The Witch, music is part of the essential fabric of the social world Hecate and her coven occupy. When Almachildes visits Hecate to secure the love charm to use on Amoretta, an act of charity (he has brought Hecate a marzipan toad from the wedding banquet) is rewarded with an invitation to dinner and entertainment in the form of a fiddling cat spirit. Later in the play the witches sing songs of comradery, freedom, and joy as they fly through the air together. And in the final witch scene, Hecate invokes a demonic inversion of the music of the spheres, 
when she says, 'let the air strike our tune, / Whilst we show reverence to yond peeping moon' (5.2.87-8) ${ }^{49}$ and the witches dance and exit. For the witches, music accompanies hospitality, friendship, and a kind of worship, and is always engaged in communally.

The court of Ravenna, on the other hand, has a very different sonic character. Whatever music might have accompanied the wedding banquet has, by the time we hear it represented on stage, devolved into disruptive noise, as evidenced by Ferdinand's comment on the impropriety: 'Not yet hath riot / Played out her last scene?' (1.1.32-3). Elsewhere, the courtiers express implicit and explicit disdain for musicians. Francisca, for example, punningly decries tobacco smokers as 'pipers,' and laments that 'tis great pity / There should not be a statute against them, / As against fiddlers' (2.1.86-8), in what is probably a reference to English statutes against wandering minstrels issued in the late sixteenth and early seventeenth centuries. ${ }^{50}$ Later, Isabella, accepting Antonio's kiss as payment for the song she has just sung him — the sole musical performance in Ravenna — says, 'I will not grumble, sir, / Like some musician' (139-40). The implication is that in accepting the kiss Isabella becomes a musician for hire but will not, as such musicians might, demand further payment. And while the comment acts as a covert jab at Antonio, who is impotent and therefore owes her more than the simple kiss he has paid her, it also calls to mind, for the audience, music's fraught status in English culture. Both are fairly minor references to music, but they both specifically draw on widely held opinions about itinerant musicians in England and the necessity of containing musical performance within strict social conventions in addition to Isabella's implied criticism of Antonio, she is clear that she performs only for the pleasure of her husband. That these two images are positioned on either side of the sole musical performance in the court suggests an important contrast to the more freely expressive and assured music of the witch scenes.

Isabella's performance itself stands in stark contrast to Hecate and her coven's rollicking song and dance routines. 'In a Maiden Time Profess'd', which she sings in an effort to convince Francisca of the virtues of marriage, is also a conventional litany of acceptable social roles for women as maids, wives, and widows:

In a maiden-time professed,

Then we say that life is best.

Tasting once the married life,

Then we only praise the wife.

There's but one state more to try,

Which makes women laugh or cry - 
Widow, widow. Of these three,

The middle's best and that give me.

$(131-8)^{51}$

The song's music, attributed to John Wilson, is fairly uncomplicated and safe, set in $\mathrm{C}$ major and proceeding in regular $4 / 4$ time..$^{52}$ Its melodic line is relatively simple - most of the vocal intervals are limited to fourths and fifths at most. A single octave leap from a low to a high $\mathrm{F}$ in the thirteenth measure, and a brief ascending scale across the fourteenth and fifteenth measures that fills a pause in the vocal line - creating some brief but ultimately unconvincing dramatic tension as the singer decides which 'of these three' versions of femininity she will choose before settling on the expected middle course - are the song's most interesting melodic features. Lyrically, the song centres on the clichés of ideal womanhood, suggesting that the range of social positions available to women are inextricable from their relationships to men as potential, actual, or departed husbands. However, the viewing and listening audience hears this song's exhortation to marry rather differently, coming as it does from a sexually frustrated wife tricked into her marriage by a man who has betrayed his best friend and is suffering from magically-induced impotence. That the song also has obvious implications for the maid Francisca, who is hiding an illegitimate pregnancy, only intensifies its irony. The song's reference to widowhood perhaps calls to mind the Duchess whose husband died in the battle that also made her the property of the Duke of Ravenna. The playful lyrics may suggest that widowhood can be a source of both laughter and tears for women but the Duchess's story makes this seem like a hollow choice. 'In a Maiden Time Profess'd', the only song sung in Ravenna, is certainly not discordant - musically or ideologically — but its place and function in the The Witch is anything but harmonious.

For the witches, on the other hand, song acts as a vehicle for the expression of both solidarity and resistance. Their first appearance in the play, in act 1 , scene 2 , situates them in a festive, free, supportive, and communal atmosphere populated almost entirely by women. The scene opens with Hecate's call to her attendant spirits and fellow witches:

Titty and Tiffin,

Suckin and Pidgen,

Liard and Robin,

White spirits, black spirits,

Grey spirits, red spirits,

Devil-toad, devil-ram, 
Devil-cat, devil dam.

Why Hoppo and Stadlin, Hellwain and Puckle!

The Witch thus introduces Hecate and her coven as a community. As Hoppo and Stadlin answer Hecate's call we learn they are 'sweating at the vessel' (9), working together to produce a magical ointment that will help them fly later in the play. That spectacular audio-visual moment arrives in act 3, scene 3, as the witches take to the air and sing 'Come Away Hecate', a song that reiterates the first witch scene's expressions of communal celebration and imagined freedom. Sung in calland-response fashion, the flying coven implores Hecate, who has remained below to speak to her son Firestone, to join them in their flight and in the simple pleasures and sense of community, intimacy, and belonging it affords.

vOICES [from off-stage or above] Come away, come away

Hecate, Hecate, $\mathrm{O}$ come away!

HECATE I come, I come, I come I come,

With all the speed I may,

With all the speed I may,

Where's Stadlin?

vOICES [from off-stage or above] Here.

HECATE

Where's Puckle?

VOICES [from off-stage or above]

Here.

And Hoppo too, and Hellwain too.

We lack but you, we lack but you.

Come away, make up the count.

HECATE I will but 'noint, and then I mount.

The song serves to situate Hecate within a cohesive community where women are free to take pleasure in one another's company. The witches' repeated calls for Hecate to join them in the air have a tenderness to them, and emphasize that the witches are all together but cannot fully enjoy their flight until Hecate joins them - they miss their friend. And as Hecate finally anoints herself with the magical oil prepared in 1.2 and joins them, the song continues, again highlighting the shared pleasure and freedom from social constraint afforded by the witches' magical powers: 
HeCATe (going up [with Cat]) Now I go, now I fly,

Malkin, my sweet spirit, and I.

$\mathrm{O}$, what a dainty pleasure 'tis

To ride in the air

When the moon shines fair

And sing and dance and toy and kiss!

Over woods, high rocks and mountains,

Over seas, our mistress' fountains,

Over steeple towers and turrets,

We fly by night 'mongst troops of spirits.

[ALL] [from off-stage or above] No ring of bells, to our ears sounds;

No howls of wolves, no yelps of hounds.

No, not the noise of waters' breach

Or cannon's throat, our height can reach.

Of note here is the focus on close physical, and perhaps even sexual, intimacy outside of the kinds of patriarchal and heteronormative social constraints that inform the dysfunctional social lives of the courtiers of Ravenna whose community is profoundly fragmented and whose desires are (destructively, it turns out) circumscribed by familial obligations, politics, patriarchal sexual mores, and the strictures of courtly conduct. ${ }^{53}$ Where the lone song sung in Ravenna is not a relief from social control but an expression of it, the witches use music as a locus for the production of social cohesion, physical freedom, and self-determination. While the witches' home is never precisely located, it exists on the geographic and economic margins of Ravenna distinct from the court but close enough that the nobles can call on the witches when required - something like Macbeth's heath. Hecate's verse above, however, describes a boundless flight - more than 5000 miles, according to Hoppo (3-4) - that covers a variety of geographies and vistas and puts them out of reach of the seat of royal power - signified by its 'steeple towers and turrets' and especially its 'cannon's throat[s]' — that would have sought to other and oppress them. ${ }^{54}$ They also frame their flight as a distinct acoustic horizon, a freedom from a series of distinctive auditory cues - church bells, ${ }^{55}$ howling wolves, yelping hounds, and gun fire - that are reminiscent of Smith's 'soundmarks'. These noises form a distinct acoustic horizon from which they are excluded. At the height of their flight, however, they cannot hear these markers, some of which not only signify normative modes of identity-making through common acoustic-geographic experience, but also evoke literal threats to the witches' precarious, liminal status outside the protection of the walls of 
Ravenna. Instead, this close-knit group of women produce their own acoustic experience of social identity and belonging through shared musical/magical experience.

In her musicological analysis of the setting for 'Come Away Hecate', Sarah Williams notes the various ways in which the music conforms to conventions that mark the musical witch as a figure of disorder: 'The bass voice keeps a relatively steady foundation while the upper voice "hiccups" in on the weak beats. The vocal range is over an octave - quite wide for vocal music at this time - and routinely features fourth, fifth, and even octave interval leaps. ${ }^{56}$ Williams reads these musical features as adjuncts to their harmless antics on stage, arguing that 'These somewhat parodic witches are depicted through not only their representation on stage as botched troublemakers but also through the disorganized and chaotic music that accompanies their innocuous demonic activities, ${ }^{57}$ I want to suggest, however, that Hecate and her coven invite us to listen to this song with witches' ears. Without question, the witches' song is the most intricate and spectacular number in the play — both visually and acoustically — and stands in stark aural contrast to the more regular and conventional tune sung by Isabella. The witches also shape our aural response to the song by explicitly inviting us to hear it in contrast to the threatening noises of the world below: the howling and yelping of animals, the raging sea, and the percussive disruptions of cannon fire, which here occupy the sonic territory evoked by the 'spindles, timbrels, rattles, or other venefical instruments' of Jonson's masque. And as Williams's analysis makes clear, "Come Away" is also a song that requires a significant degree of skill to manage its demanding vocal leaps. It may be 'disorganized and chaotic' but the song is also virtuosic, exotic, and fun. In a very literal way, the piece is exactly what Middleton's theatre-going audience came for (this play is, after all, called The Witch). At the same time, as Simon Smith has recently shown, early modern playhouse music frequently invited playgoers to identify with marginal characters, encouraging them to 'revel in the difference of the performing character and simultaneously to adopt his or her identity for a few moments, exploring an alternative viewpoint through the dual perspective of distance and identification. ${ }^{58}$ The frequent use of inclusive pronouns such as 'we' and 'our' in the song invite the audience imaginatively into the witches' community, and the pleasures they express encourage the audience to revel in the possibility of freedom from both abstract social constraint and specific forms of oppression. ${ }^{59}$ Though their appearances, behaviours, and even the surface unruliness of their music marks their difference from the London playhouse audience, the song's obvious entertainment value alongside the explicit indications in the text that the witches take pleasure in their collective moments 
of musical expression and reject the noise of the world below, invite the audience to temporarily bridge that difference. ${ }^{60}$ If we listen with witches' ears, as the lyrics invite us to do, the song is harmonious, and, in a fascinating inversion of Jonson's musical revels, represents both musical and social concord centred not on royal authority and inclusion in the privileges of court but on Hecate and her fellow witches in vibrant, communal bonding.

I want to note, at this point, one obvious exception to the sense of inclusiveness and social harmony generated by the witches' music. Hecate's son Firestone, the only definitely male character in the witches' coven, ${ }^{61}$ is also the only member of the witches' community who is not allowed to join in the magical flight and the songs and dances they use to express their social cohesion and friendship. In fact, Firestone is explicitly marked out as responsible for the domestic labour in Hecate's home. Just before the magical flight begins he arrives with magical herbs and remarks that his body aches from bending down to collect them, and Hecate hurrying to join her sweet sisters in the air - leaves him behind to clean the house (20-33). This example is, in one sense, a simple inversion of the ordinary hierarchy; Firestone is made to occupy the private domestic sphere, engaging in conventional 'women's work', while Hecate and her coven go out. But Firestone's role in the witch scenes is also to remind us that even an inverted patriarchy contains an inherent threat to its women. In Firestone's very first moments on stage, in which he has revealed to us that Hecate is three years away from the end of her allotted 120 years on earth, he responds to his mother's description of a powerful poison she has concocted in an aside: "Dear syrup", call you it? A little thing / Would make me give you a dram on't, in a posset, / And cut you three years shorter' (1.2.83-5). And in a later aside, just before the magical flight in 3.3, he wishes his mother would fall from her flight and break her neck, 'That I might have all quickly!' (35). Firestone's murderous imagination, and his fixation on the power and material gain (however modest) he will achieve when his mother dies serves to link him with the men of Ravenna, a link reinforced by Hecate's comment about Firestone's desire to 'overlay a fat parson's daughter' while she's out: 'You're a kind son; / But 'tis the nature of you all, I see that. / You had rather hunt after strange women still / Than lie with your own mothers' (1.2.95-8). The remark, read in conjunction with Firestone's plotting, is an implicit acknowledgement of the heart of the problem in Ravenna: greed and desire make men behave badly and threaten women. Though he is ultimately harmless in the play, Firestone, as the only male in the witch coven, represents what the women must contain or escape in order to ensure their freedom and autonomy. Their solidarity and their joyful expressions of female friendship involve excluding him from 
the music, and leaving him behind, just as they have left behind the noise against which their disorderly music can be heard as harmonious.

The play's final witch scene (5.2), in which Hecate and the others produce a poison for the Duchess that will dispatch Almachildes, contains two further song performances that move beyond the more diffuse and general connection between music and social cohesion in 'Come Away Hecate' to explicitly invoke the musical tropes mobilized in works such as The Masque of Queens. Following Peter Walls, Eubanks Winkler observes that in Queens, the witches' magical charms are spoken and not sung, and they remain notably ineffectual: 'Sung music and its special magical powers are reserved for the noble participants of the masque proper'. ${ }^{62}$ While no definite setting survives, the charm that produces the Duchess's poison is identified in a stage direction as 'a charm song about a vessel', and its text suggests another call-and-response number that involves the full participation of the play's witches, highlighting their unity:

HECATE Black spirits and white, red spirits and grey

Mingle, mingle, mingle, you that mingle may.

Titty, Tiffin, keep it stiff in.

Firedrake, Puckey, make it lucky.

Liard, Robin, you must bob in.

Round, around, around, about, about

All ill coming running in, all good keep out.

The song's refrain, couched in the conventional language of overturned hierarchies we might expect from a witch play, is less a simple othering of the witches here than a reminder that for witches, marginalization through such othering can be embraced as a source of shared identity and community. And that sense of community is, in the song's second verse, clearly aligned with the charm's effectiveness, as each of the witches adds ingredients to the vessel and contributes to the concoction (70-77).

The play's final musical moment, however, offers its most sophisticated complication of the musical tropes conventionally deployed in works such as The Masque of Queens to mark and contain the malevolent otherness of witches. When the members of the coven have completed their charm, Hecate calls, 'Come, my sweet sisters, let the air strike our tune / Whilst we show reverence to yond peeping moon', and a stage direction tells us, 'Here they dance The Witches' Dance and exeunt' (87-8 s.d). As Marion O'Connor's note indicates, this stage direction possibly refers to one of the two witches' dances composed by Robert Johnson for the Masque of Queens. She notes that 'current opinion about the genesis 
of the witches' dances leaves open the hypothesis that one of them might have been recycled for Thomas Middleton's play' but goes on to acknowledge that the manuscript sources for the songs 'cannot be taken as more than an ensemble of possibilities for the performance of The Witch in 1616.63 Eubanks Winkler, taking seriously an early suggestion by John Cutts that The Witch in fact reused the music from Queens, ${ }^{64}$ offers us a useful speculative reading of how such a borrowing might have resonated for an audience familiar with the masque itself, the printed text and description published shortly after its performance, or more broadly with the ideas and conventions it mobilized. If indeed the play borrowed Johnson's music, she argues, their final appearance consists of 'a grotesque antimasque dance, which, in its original context, musically and visually emphasized the hags' estrangement from the idealized harmony of the aristocratic body. However, unlike Jonson's hags, Middleton's coven is not dispelled by courtly order, by the loud music of Fame. Hecate and her cohorts simply disappear. ${ }^{65}$ In the absence of additional records, we simply cannot know if this was the case or not. The reading of The Witch I have offered here, however, understands its musical tropes as in dialogue with and indeed inverting and satirizing the conventions of musical representations of witches in early modern England exemplified by court entertainments such as Jonson's masque and lends some additional weight to the possibility. And even if the music itself was not duplicated there seems to be an obvious parallel to the antimasque dance that intensifies, as Eubanks Winkler suggests, the implications of the witches' disappearance at the end of the scene. But where Eubanks Winkler calls the moment grotesque, I argue that we again need to recognize the ways in which the play invites us to share the witches' acoustic horizon. Throughout the play the witches have built a functional musical community through shared musical practices that directly and indirectly invoke the notions of social harmony that circulated in the network of ideas connected to music in the early modern English imagination. Listening to it with witches' ears, the antimasque dance is not grotesque and othering, but, like their earlier songs, celebratory and communal. Rather than marked and contained as an unruly dissonance, their disruptive antimasque banished from the stage and the women punished for their transgressions as they presumably are in Jonson's masque, Middleton's play sees Hecate and her 'sweet sisters' escape unharmed after their joyful revels, and their harmony — however it may sound — is the last music that the audience hears.

By taking these singing witches seriously, and by listening to their music with witches' ears, we can recover a sense of the sophistication with which Middleton deploys music in service of a more poignant and more far-reaching satire than 
critics have typically ascribed to The Witch. Hecate and her coven are more than just entertainers (though they are, without question, entertaining) and their performances offer audiences more than mere spectacle (though they do, without question, deliver on the spectacle). Interpolating and inverting the musical dynamics of court masques, and particularly Jonson's Masque of Queens, Middleton's musical coven forges and celebrates an alternative community through shared musical practices and decentres the courtly elite as the wellspring of productive social identity. By taking the antimasque and making an anti-masque, where the harmony of witches is contrasted with the disorders inherent in conventional, patriarchal forms of social organization and power, Middleton offers his theatregoers a unique opportunity to consider from whence musical community arises: the exclusionary, abstract, and often corrupt conventions of royal and courtly authority, or the participatory, inclusive, and joyful practices of a group of women on the margins trying to get by with a little help from their friends.

\section{Notes}

Like the songs sung by Hecate and her coven, this essay emerges from the magic of a supportive community that I would like to briefly acknowledge here. Jennifer Panek patiently ushered me through the thinking and writing that formed the earliest version of this argument. Meg Pearson's judicious edits on an early draft offered just the right balance of incisive questions and encouraging exclamation marks when I was much in need of both. An incomparably keen and insightful group of fourth-year undergraduate students in my Staging the Supernatural seminar at Trent University in the fall of 2019 acted as a sounding board for some of the ideas presented here, and their excitement about this play helped to elevate and sustain my own. And finally, the two anonymous readers for this journal were models of academic generosity and their insightful feedback has significantly strengthened the final version of the argument.

1 On the dating of the play, see Marion O'Connor's entry for The Witch in 'Canon and Chronology', in Thomas Middleton, Vol. 2: Thomas Middleton and Early Modern Textual Culture, A Companion to the Collected Works, ed. Gary Taylor and John Lavagnino (Oxford University Press, 2007), 382-3. https://doi.org/10.1093/ actrade/9780198185703.book.1.

2 The provenance of Macbeth's two scenes featuring Hecate (3.5 and 4.1), and the hand that Middleton himself may have played in the interpolation, has been the focus of much critical discussion of Middleton's play. A brief summary of that 
discussion, alongside a detailed textual analysis of the two plays that supports the role of Middleton as the adaptor of Macbeth, can be found in Gary Taylor, 'Empirical Middleton: Macbeth, Adaptation, and Microauthorship', Shakespeare Quarterly 65.3 (2014), 239-72, https://doi.org/10.1353/shq.2014.0030.

3 See Amanda Eubanks Winkler, O Let Us Howle Some Heavy Note: Music for Witches, the Melancholic and the Mad on the Seventeenth Century English Stage (Bloomington, 2006), 23, https://doi.org/10.2307/j.ctt2005sqt.

4 For useful overviews of the ideological debates surrounding the use and value of music in early modern England see David Lindley, Shakespeare and Music (London, 2006), 13-49, https://doi.org/10.5040/9781472555182 and Christopher Marsh, Music and Society in Early Modern England (Cambridge, 2010), 32-70. On the role of music in religious life in the period, see Hyun-Ah Kim, Humanism and the Reform of Sacred Music in Early Modern England (Farnham, 2008), https://doi. org/10.4324/9781315587585, and Katherine Steele Brokaw, Staging Harmony: Music and Religious Change in Late Medieval and Early Modern English Drama (Ithaca, 2016), https://doi.org/10.7591/9781501705915. On the politics of music, see Joseph Ortiz, Broken Harmony: Shakespeare and the Politics of Music (Ithaca, 2011), https:// doi.org/10.7591/9780801460920. On music as subjective experience and as a facilitator of intersubjective connections between performer and listener, see Simon Smith, Musical Response in the Early Modern Playhouse, 1603-1625 (Cambridge, 2017), 103-44, https://doi.org/10.1017/9781316848333.

5 See Roy Booth, 'Witchcraft, Flight and the Early Modern English Stage', Early Modern Literary Studies 13.1 (2007), np.

6 Diane Purkiss, The Witch in History: Early Modern and Twentieth-Century Representations (London, 1996), 214, https://doi.org/10.4324/9780203359723.

7 See Anne Lancashire, 'The Witch: Stage Flop or Political Mistake?', in 'Accompaninge the Players': Essays in Celebration of Thomas Middleton, 1580-1980, ed. Kenneth Friedenreich (New York, 1983), 161-81.

8 Originally suggested by W.J. Lawrence in Shakespeare's Workshop (Boston, 1928), 28-33, and now generally accepted by critics of The Witch. See Peter Corbin and Douglas Sedge, eds, 'Introduction', Three Jacobean Witchcraft Plays (Manchester, 1986), 1; Purkiss, The Witch in History, 214; Sarah Williams, 'Now Rise Infernal Tones': The Representation of Early Modern English Witchcraft in Sound and Music, PhD Thesis (Northwestern University, 2006), 268; Gary Taylor and Andrew Sabol, 'Middleton, Music, and Dance', in Thomas Middleton, Vol. 2: Thomas Middleton and Early Modern Textual Culture, ed. Gary Taylor and John Lavagnino (Oxford, 2007), 130, https://doi.org/10.1093/actrade/9780198185703.book.1; Tiffany Stern, 'Middleton's Collaborators in Music and Song', in The Oxford Handbook of Thomas 
Middleton, ed. Gary Taylor and Trish Thomas Henley (Oxford, 2012), 75, https:// doi.org/10.1093/oxfordhb/9780199559886.001.0001.

9 Purkiss, The Witch in History, 214.

10 No evidence exists that Middleton attended Jonson's masque. I intend only to suggest a shared awareness of the musical ideas and practices that animated Queens. More likely is that Middleton - like some, but certainly not all, of his theatrical audience - read the published version of the masque text (published in quarto in 1609 , soon after the performance) and supplemented it with the first-hand experience of the players in the King's Men, who performed The Witch in 1616, and had also performed the witches' roles in the Queens antimasque. For more on Middleton's reuse of musical material from Queens, see Stern, 'Middleton's Collaborators', 74-5. On Middleton's use of tropes and techniques borrowed from masque culture, see Caroline Baird, 'From Court to Playhouse and Back: Middleton's Appropriation of the Masque', Early Theatre 18.2 (2015), 57-85, https://doi.org/10.12745/ et.18.2.2517. On the cultural awareness of the details of masque performances beyond the court, including the circulation of printed descriptions, see Lauren Sohet, 'Reading/Genres: On 1630s Masques', in Spectacle and Public Performance in the Late Middle Ages and the Renaissance, ed. Robert E. Stillman (Leiden, 2006), 233, and Martin Butler, The Stuart Court Masque and Political Culture (Cambridge, 2008), 3.

11 Corbin and Sedge, 'Introduction', 16.

12 Linda Austern, "'Art to Enchant": Musical Magic and its Practitioners in English Renaissance Drama', Journal of the Royal Musical Association 115.2 (1990), 201, 202, https://doi.org/10.1093/jrma/115.2.191.

13 Paul Yachnin, 'Scandalous Trades: Middleton's "The Witch," the "Populuxe” Market, and the Politics of the Theater', Medieval and Renaissance Drama in England 12 (1999), 231.

14 Elizabeth Schafer (ed.), 'Introduction', The Witch (London, 1994), xx.

15 Purkiss, The Witch in History, 218. See also Julia M Garret, 'Witchcraft and Sexual Knowledge in Early Modern England', The Journal of Early Modern Cultural Studies 13.1 (2013), 46, https://doi.org/10.1353/jem.2013.0002.

16 Eubanks Winkler, O Let Us Howle, 32.

17 Ian Bostridge, Witchcraft and Its Transformations c. 1650-1750 (Oxford, 1997), 2, https://doi.org/10.1093/acprof:oso/9780198206538.001.0001.

18 Stuart Clark, 'Inversion, Misrule, and the Meaning of Witchcraft', Past and Present 87 (1980), 100, https://doi.org/10.1093/past/87.1.98.

19 Stuart Clark, Thinking With Demons: The Idea of Witchcraft in Early Modern Europe (Oxford, 1997), 552, http://doi.org/10.1093/acprof:oso/9780198208082.001.0001. 
20 Peter Elmer, Witchcraft, Witch-Hunting, and Politics in Early Modern England (Oxford, 2016), 5, http://doi.org/10.1093/acprof:oso/9780198717720.001.0001.

21 Bostridge, Clark, and — to a limited and more nuanced extent — Elmer represent what is sometimes referred to by historians as the 'top-down' model of witchcraft historiography. This method is, of course, only one approach. I rely on it here because it is germane to our understanding of Jonson's highly learned and explicitly ideological representation of witches in the antimasque of Queens and because, as I will show, such ideological aims are the target of Middleton's satire in his play. For the 'bottom-up' approach, which prioritizes a broader range of archival documents to excavate the specific, local practices and impacts of early modern witchcraft beliefs on the lives of both accusers and accused see, for example, the equally influential and invaluable work of Alan Macfarlane, Witchcraft in Tudor and Stuart England: A Regional and Comparative Study (London, 1970), https://doi.org/10.1086/ ahr/76.4.1164; Keith Thomas, Religion and the Decline of Magic (New York, 1971); James Sharpe, Instruments of Darkness: Witchcraft in Early Modern England (Philadelphia, 1996); Marion Gibson, Reading Witchcraft: Stories of Early English Witches (New York, 1999). More detailed and thorough reviews of witchcraft historiography can be found in Malcolm Gaskill, 'Witchcraft Trials in England', The Oxford Handbook of Witchcraft in Early Modern Europe and Colonial America (Oxford, 2013), 283-98, https://doi.org/10.1093/oxfordhb/9780199578160.013.0017, and Charlotte Rose Millar, Witchcraft, the Devil, and Emotions (London, 2017), 7-12, https://doi. org/10.4324/9781315547015.

22 Eubanks Winkler, O Let Us Howle, 25.

23 The formal antimasque is a Jonsonian innovation which, as his notes to Queens indicate, he had first experimented with in The Lord Haddington's Masque a year earlier, but which was more fully realized and integrated, at the request of Queen Anne, into The Masque of Queens. See Ben Jonson, 'The Masque of Queens', in Ben Jonson: The Complete Masques, ed. Stephen Orgel (New Haven, 1969), 122-3.

24 James Carmichael, News from Scotland (London, 1592; STC: 10842), A2v-C1r.

25 A good summary of the Essex divorce scandal, sometimes also known as the Overbury affair, can be found in Schafer, 'Introduction', xv-xix

26 Thomas Elyot, The Book Named the Governor (London, 1537; STC: 7636), 23r.

27 William Shakespeare, 'The History of Troilus and Cressida', in The Riverside Shakespeare $2^{\text {nd }}$ edn, ed. G. Blakemore Evans (Boston, 1997), 477-532. This passage, as well as the one from Elyot above, are perhaps the two most frequently cited early modern sources for ideas about music's role in early modern conceptions of social organization. See, for example, Lindley, Shakespeare and Music, 20-1; Marsh, Music and Society, especially 15-22 and 44-5. Further discussion of the imaginative link 
between music and social harmony, including additional primary sources, can be found in Eubanks Winkler, O Let Us Howle, 1-7, and Ortiz, Broken Harmony, 142179.

28 Marsh, Music and Society, 57.

29 Bruce R. Smith, The Acoustic World of Early Modern England: Attending to the OFactor (Chicago, 1999), 46.

30 Wes Folkerth, The Sound of Shakespeare (London, 2002), 39, https://doi. org/10.4324/9781315811994.

31 On the ubiquity of musical performance in early modern English life, see Lindley, Shakespeare and Music, 50-103 and Marsh, Music and Society, 1-31.

32 David Lindley, 'Musical Community in Early Modern Theatre', in CommunityMaking in Early Stuart Theatres: Stage and Audience, ed Roger Sell, Anthony Johnson, and Helen Wilcox (London, 2017), 161, https://doi.org/10.4324/9781315573014.

33 On the relationship between witchcraft and musical community building in two later early modern plays, see Andrew Loeb, "My poor fiddle is bewitched": Music, Magic, and the Theatre in The Witch of Edmonton and The Late Lancashire Witches', in Magical Transformation on the Early Modern English Stage, ed. Lisa Hopkins and Helen Ostovich (Farnham, 2014), 215-32, https://doi.org/10.4324/9781315593197.

34 Quotations from the masque are cited by line number and refer to Ben Jonson, 'The Masque of Queens', in Ben Jonson: The Complete Masques, ed. Stephen Orgel (New Haven, 1969), 122-41.

35 Kristen McDermott, ed., 'Introduction', in Masques of Difference: Four Court Masques by Ben Jonson (Manchester, 2007), 5.

36 On the use of 'hollow and infernal music' in The Masque of Queens and elsewhere to denote otherness, see Jennifer Linhart Wood, 'Listening to Black Magic Women: The Early Modern Songscapes of Witch Drama and the New World', in Gender and Song in Early Modern England, ed. Leslie C. Dunn and Katherine R. Larson (London, 2014), 47-62, https://doi.org/10.4324/9781315583952.

37 For the musical setting and discussions of the provenance and possible authorship of it, see Taylor and Sabol, 'Middleton, Music, and Dance', 158-161, and Eubanks Winkler, O Let Us Howle, 33, 190n51.

38 Eubanks Winkler, O Let Us Howle, 31-2.

39 Purkiss, The Witch in History, 200.

40 Martin Butler, 'Courtly Negotiations', in The Politics of the Stuart Court Masque, ed. David Bevington and Peter Holbrook (Cambridge, 1998), 20.

41 McDermott, 'Introduction', 44.

42 Bruce R. Smith, The Acoustic World, 92. See also David Lindley, 'The Politics of Music in the Masque', in The Politics of the Stuart Court Masque, ed. David Bevington 
and Peter Holbrook (Cambridge, 1998), 275: 'Up to 100 musicians ... might have been employed, an ensemble only possible at court, and making therefore a significant contribution to the assertion of royal magnificence'.

43 Of the neoplatonic symbolism of the unison, one early modern writer notes that, 'Musicke is none other than a perfect harmonie, whose divinitie is seene in the perfectnesse of his proportions, as, his unison sheweth the unitie, from whence all other, (concords, discords, consonancies, or others whatsoever) springeth'. See Thomas Robinson, The Schoole of Musicke (London, 1603; STC: 21128), qtd. in Eubanks Winkler, O Let Us Howle, 1.

44 Butler, 'Courtly Negotiations', 5.

45 Butler, 'The Stuart Court Masque', 3.

46 See McDermott, 'Introduction', 39-40 for historical examples of the complicated diplomatic and patronage-related negotiations that circulated in the background of the preparation for and performance of Queens.

47 Barbara Ravelhofer, The Early Stuart Court Masque: Dance, Costume, and Music (Oxford, 2006), 64.

48 Mary Chan, Music in the Theatre of Ben Jonson (Oxford, 1980), 139.

49 In-text act, scene, and line numbers refer to the edition of the play edited by Marion O'Connor, The Witch in Thomas Middleton, Vol. 1: The Collected Works, ed. Gary Taylor and John Lavagnino (Oxford, 2007), 1129-64. https://doi.org/10.1093/ actrade/9780199580538.book.1.

50 See Schafer, 'Introduction', 28, and O'Connor, The Witch, 1141 and note.

51 O'Connor, in an editorial note to these lines, points out that while the play text only includes the first verse, musical settings for the song include two further verses with increasingly bawdy content. She argues that while the additional verses are inappropriate to both the character and the dramatic situation, they may have fit with the play's topical satire of the scandal involving Frances Howard and Robert Carr, since Middleton had earlier written a wedding masque for the couple called The Masque of Cupids (1614). We cannot, however, tell from the play text alone whether just the first or all three verses were sung during this moment in the play.

52 For the setting, see Taylor and Sabol, 'Middleton, Music, and Dance', 151, and Schafer, 'Introduction', 90-1. The variant included in Schafer includes the text of the two additional verses mentioned in note 51 .

53 The simplest reading of the intimacy implied by 'toy and kiss' in these lines is that it occurs between witch and familiar or spirit, a trope of early modern witch beliefs evidenced by pamphlets such as Henry Goodcole's The Wonderful Discovery of Elizabeth Sawyer, A Witch (London, 1621; STC: 12014). Indeed, this is made explicit by the offstage voice that tells us Malkin descends 'to fetch his dues: / A kiss, a coll, a sip 
of blood' a few lines earlier (3.3.49-50). But the possibility is left open for intimacy between the witches themselves, as the line is situated amongst a series of pleasures experienced by the group as a whole, 'Over ... our mistress' fountains' (66, emphasis mine). The plural possessive here suggests the group as a whole may engage in such expressions of physical intimacy.

54 Booth, 'Witchcraft, Flight, and the Early Modern Stage', par. 20.

55 On church bells as acoustic symbols of parish power, 'village voices' calling parishioners to collective action, and potent aural defenders against malignant forces both natural and unnatural, see Margaret Aston, Broken Idols of the English Reformation (Cambridge, 2016), 450-65.

56 Williams, 'Now Rise Infernal Tones', 270.

57 Ibid.

58 Smith, Musical Response, 120-30. Smith's argument centres primarily on the songs performed by the gypsy characters in Dekker, Ford, Middelton, and Rowley's The Spanish Gypsy (1623), but his broader argument that songs can encourage identification with the socially marginalized 'other' applies in obvious ways to witches as well.

59 Ibid, 124-6.

60 The witches' diabolical actions in the play — skinning snakes, fashioning poisons, incest, bestiality, and even murdering infants and young girls — are akin to Jonson's 'spectacle $[s]$ of strangeness', marking the witches as radically other to normative Englishness. However, within the context of the play this is crucial to Middleton's satirical aims. The witches' behaviours are obviously no worse than those exhibited by the courtiers. And while they might be read as externally malevolent, much of that malevolence is significantly tempered. In an early exchange, Hecate makes clear that her acts of maleficia against some local farmers are in response to refused charity (1.2.43-61). They attempt to kill or charm the courtiers only when paid to do so by those courtiers' human enemies. Hecate and Firestone have an explicitly incestuous relationship, but one that is apparently mutual and consensual and free from jealousy — Hecate agrees to 'make shift ... for once' with Malkin the cat instead of her son (95) — and stands in contrast to Antonio's unusual preoccupation with his sister Francisca's chastity (this insightful observation was suggested to me by Albana Stafa, a student in my Staging the Supernatural seminar at Trent University in the fall of 2019). The 'unbaptized brat' (15) and 'three ounces of the red-haired girl / [Hecate] killed last night' (5.2.58-9) shock at first, but are almost certainly no more shocking than the ruthlessness of the several revenge plots in the court, including the Duke's gruesome ritual of drinking from his wife's father's skull. The play as a whole implicitly invites us to ask who we are really afraid of here. 
61 On the uncertain and perhaps fluid gender of Malkin the cat, see Pierre Kapitaniak, 'From Intertextual to Gender Transgression in Middleton's The Witch', in The Circulation of Knowledge in Early Modern English Literature, ed. Sophie Chiari (London, 2016), 194-7, https://doi.org/10.4324/9781315614724.

62 Eubanks Winkler, O Let Us Howle, 26.

63 O'Connor, The Witch, 1162.

64 See John P. Cutts, 'Robert Johnson and the Court Masque', Music and Letters 41.2 (1960), 111-26, https://doi.org/10.1093/ml/41.2.111.

65 Eubanks Winkler, O Let Us Howle, 34. 
